\title{
Informing and Interacting with Citizens: A Strategic Communication Review of the Websites of the ECOWAS Parliaments
}

\section{Aminu Hamajoda*}

National institute for legislative studies, Abuja, Nigeria

\begin{abstract}
This is an evaluation of ECOWAS members' websites based on a modified version of the guidelines recommended by Inter-Parliamentary Union (IPU) in 2009. The appraisal under several headings, are suggested to help parliaments plan and oversee their websites in a modern age where the internet provide a continuously significant platform for interacting and communicating with the general public. The study finds out that while most Member States websites score well on general information about their parliaments, they lacked progress in making their websites a one-stop point for political information about their countries, and a fulcrum for interaction between legislators and citizens and a real time deliberation on burning national and regional issues despite the current availability of suitable interactive tools on the internet.
\end{abstract}

Keywords: ECOWAS parliaments; Parliamentary website; Parliamentary communication; Political communication

\section{Introduction}

The Economic Community of West African States (ECOWAS) recently celebrated its $40^{\text {th }}$ anniversary in 2015 touting collective security and the relative free movement of people and goods as some of its achievements. ECOWAS lofty Vision [1] promises "to create a borderless, prosperous and cohesive region, built on good governance and where people have capacity to access and harness its enormous resources through the creation of opportunities for sustainable development and environmental preservation". Founded in 1975, the ECOWAS has 15 members, consisting of former English, French and Portuguese colonies.

Only Nigeria and Liberia (Table 1) operate bicameral legislatures, while all the others are unicameral legislatures with their parliaments headed by either speakers or presidents. Apart from Guinea, Mali and Senegal, all other members have accessible websites (as of 26-1-2016). Senegalese Parliament website has a notice of on-going construction on its website. African Parliaments are seen as fulcrums for the strengthening of democratic cultures in Africa especially as legislators combine the three vital functions of representation, lawmaking and oversight. As early as 2011, [2] reports how ECOWAS had deemed it necessary to formulate an information and communication policy suitable for the commission's drive for regional integration

\begin{tabular}{|c|c|c|c|}
\hline Benin & http://www.assemblee-nationale.bj/ & Unicameral & French \\
\hline Burkina Faso & http://www.assembleenationale.bf/ & Unicameral & French \\
\hline Cape Verde & http://www.parlamento.cv/ & unicameral & Portuguese \\
\hline Gambia & http://www.assembly.gov.gm/ & Unicameral & English \\
\hline Ghana & http://www.parliament.gh/ & Unicameral & English \\
\hline Guinea & No website & Unicameral & French \\
\hline Guinea-Bissau & http://www.anpguinebissau.org/ & Unicameral & Portuguese \\
\hline Ivory Coast & http://www.assnat.ci/ & Unicameral & French \\
\hline piberia & http://legislature.gov.Ir/ & Bicameral & English \\
\hline Mali & http://www.primature.gov.ml/ & Unicameral & French \\
\hline Niger & http://www.assemblee.ne/ & Unicameral & French \\
\hline Nigeria & http://nass.gov.ng/ & Bicameral & English \\
\hline - Senegal & http://www.assemblee-nationale.sn/ & Unicameral & French \\
\hline Sierra Leone & http://www.parliament.gov.sl/ & Unicameral & French \\
\hline$\star$ Togo & http://www.assemblee-nationale.tg & Unicameral & French \\
\hline
\end{tabular}

Table 1: List of Member States of ECOWAS. that had shifted from 'states ECOWAS' to 'people ECOWAS' to be sustained mainly on five pillars: Good governance, Infrastructural development, Involvement of women, youth and children, private sector participation, sustainable natural resources and environment utilization. 'People ECOWAS' is also predicated on the implementation of ECOWAS vision 2020. Four components according to Sanakoua underpin the new information and communication strategy: information of the population, action visibility, capacity building and population participation and their feedback. From the foregoing, it is clear that interactive political and social communication between the citizens of ECOWAS countries and member states is necessary for creating awareness and mobilization of citizens, two vital imperatives in ECOWAS desire for regional integration and collective security. One of the most promising interactive platform is the website, which is becoming a portent tool for social mobilization and broadening of political participation mainly because of the convergence of interactive and purely informational tools on it. Many studies identify the inherent potentiality of interactive communication that the internet portents by bestowing political power through real time voting and the expression of opinions on issues. Online interactivity could also change the representational and constituency structures of relations in many nations as the internet increase in capacity and speed. This study has drawn mainly from the revised Inter-parliamentary Union (IPU:2000 approved at its $166^{\text {th }}$ Session) Guidelines for Parliamentary Websites to prepare an abridged assessment form (Appendix A) in order to evaluate and score ECOWAS parliamentary websites by assessing their stages of development based on the core expectations of the guidelines. I have in the process of designing the form also consulted the revised 2009 version, but had maintained the 2000 version subheadings. I have also evaded some features like website design, budget and oversight to avoid subjectivity and in recognition of IPU's assertion that although

*Corresponding author: Hamajoda A, National institute for legislative studies, Abuja, Nigeria, E-mail: aminufhamajoda@yahoo.com

Received April 14, 2016; Accepted April 27, 2016; Published April 30, 2016

Citation: Hamajoda A (2016) Informing and Interacting with Citizens: A Strategic Communication Review of the Websites of the ECOWAS Parliaments. J Mass Communicat Journalism 6: 295. doi:10.4172/2165-7912.1000295

Copyright: (c) 2016 Hamajoda A. This is an open-access article distributed under the terms of the Creative Commons Attribution License, which permits unrestricted use, distribution, and reproduction in any medium, provided the original author and source are credited. 
the guidelines are universal, their contextual applicability must be considered. This is more so as budget, oversight and technical management reports are almost non-existent currently on members' websites. The Guidelines were revised in 1998 by Global Centre for ICT in Parliament, in consultation with the IPU to keep pace with the fast development in internet technology. Basically the new version updated the 2000 version. According to IPU (2009:9) in a summary, "During the past decade the objectives of parliamentary websites have become more complex and more challenging. They began with the goal of providing basic information about the history, the functions, and the members of the legislature. They were soon tasked to provide copies of official texts of proposed legislation, then the verbatim accounts of debates and summaries of plenary actions, and copies of committee documents. As the interactive web has emerged they have added tools that encourage two-way communication between members and citizens, inviting them to share their views and possibly engaging them in the policy process". In this paper, I have, under each major category scored parliaments by discussing the implications of the progress and shortcomings of the various features to political communication, mass participation, and policy deliberation on societal issues.

\section{Literature Review}

Numerous studies show how African countries can potentially benefit from modern electronic platforms especially the increasing importance of websites as interactive receptacles of communication. Kindra [3] presents a communication plan that can help legislatures fortify their relationships with the electorate. They argue that interactive communicative platforms can educate, consult, build consensus, legitimize governance, resolve conflicts, and bring policies to public scrutiny. They further suggest how modern communication platforms including social media, open up channels of interaction between the electorates and legislators, quite often in real time. By so doing, they argue, legislators as representatives can sharpen their skills in all forms of communication - written, oral and visual. Coleman [4] however doused the high expectations of the internet serving as a competent tool for political consultation with citizens. In a study of the on-line parliamentary consultation of the UK parliament between 1998 to 2002, he acknowledges the demise of unidirectional political communication that dominated the best part of the $20^{\text {th }}$ century, but reiterates the persistent challenges of 'public remoteness' and 'lack of openness'. He also questions the quality of public policy deliberation on-line, which he views as full of snappy, abusive and thoughtless comments. The importance of communication between parliaments and citizens however has grown in the past ten years mainly because traditional channels like political parties are currently challenged. Pellizo [5] notes the dramatic decline of parties as linkages to the electorates in terms of a two-way communication. According to them, the decline is mainly due to their loss as grassroots mobilisers and channels of communication. Their study also acknowledges the lowlevel trust for legislators across the globe, including advanced countries like USA and Germany (where 8 out of 10 citizens don't trust their legislators) and the poor implementation of parliamentary websites despite the appreciation of their enormous potential.

It is concerning implementation that Oni [6] especially note the lowlevel of interactivity of African websites considering the potential of a two-way relationships that could be embedded in an online interactive website. As of the time of their study, only Angolan parliament accepts electronic submissions from its electorate in Africa. They conclude their study therefore by pointing out that despite the essence of democratic governance, online interaction between legislators and citizens are still being developed in Africa. Websites they observe are unidirectional, mere informational, posting legislative documents and making them downloadable in PDF format.

\section{Methodology}

A form (Appendix ' $A$ ') was designed with 10 general categories consisting of key sub-features: General information on the structure of the parliament, Electoral systems and Parties, Legislative process and documents, Presiding Officers of the Parliament, Members of the Parliament, Parliamentary bodies, Publications of the parliament, Electronic media contents, External links and Feedback and interactivity Tools of the parliament. The binary method of yes/no translating to 0 or 1 was used to score the features under each category, making the total possible score to be 62 (the number of total features). A database based on the fields of the form was created and 12 ECOWAS member countries out of 15 were previewed and scored. The websites are in French, English and Portuguese, necessitating the intensive use of Microsoft online translation tool, which was very effective except in automatically reading PDF documents and picture form banners. Guinea and Mali have no functional websites, while that of Senegal is still under construction as of the time of this study (January 2016). After the entry of data for each of the 12 parliaments, the results of the queries for each category was pasted in a spread sheet program for scoring and graphing exercise (Figure 1).

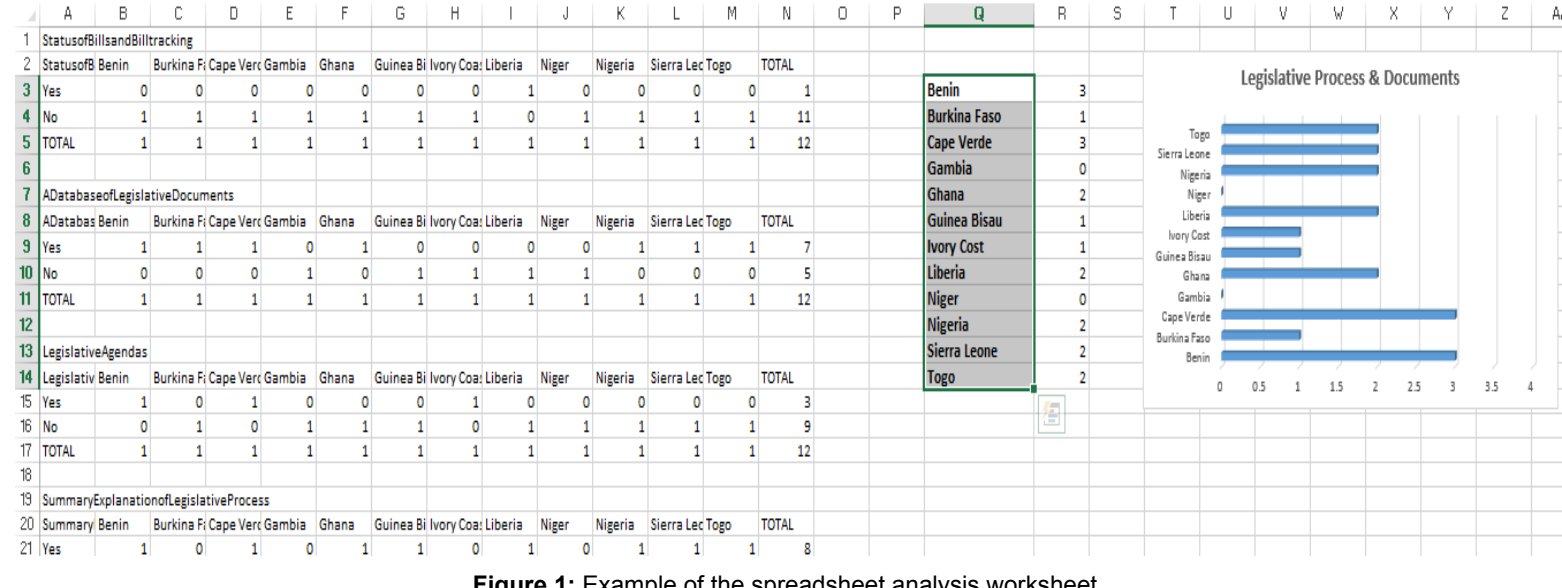

Figure 1: Example of the spreadsheet analysis worksheet. 
Citation: Hamajoda A (2016) Informing and Interacting with Citizens: A Strategic Communication Review of the Websites of the ECOWAS Parliaments J Mass Communicat Journalism 6: 295. doi:10.4172/2165-7912.1000295

\section{Results and Discussion}

Africa had scored 23\% in World E-parliament Report 2010 [7], less than Latin American 46\% and EU's 69\% in parliamentary websites. This pattern had continued in the 2012 report [8], not much has changed in sub-Saharan Africa considering the comparative scores of ECOWAS Parliaments based on the adapted IPU 2009 Guidelines (Figure 2).

Only the Benin Republic Parliament scores up to 30 out of the total 62 points, indicating that none of the assessed websites have implemented up to $50 \%$ of IPU recommendations. Although the World E-parliament Report 2010 attributes the low level implementation to lack of resources, it appears most websites are still under construction and facing the challenges of establishing a management and technical structure and creating a system of document and content management of the websites.

\section{General Information on the Structure of the Parliament}

The general information on a parliament is the most important segment of a website. It serves as a preface to establishing a communicative relation with citizens. Brassard [9] years ago foresaw the evolving public expectation of institutions vis-à-vis the development of the internet. According to him, public expect a timely response, an acceptable adequacy of information online and an acceptable access to knowledge of parliamentary process and documents (Figure 3).

Under this segment, there are 15 selected features; the full text of rules and procedures in the parliament, a brief history of the parliament, a list of related non-parliamentary bodies, explanation of each parliamentary segment, a downloadable text of the country's constitution, its membership to international organizations, information on how to

Member Countries' Scores out of 62

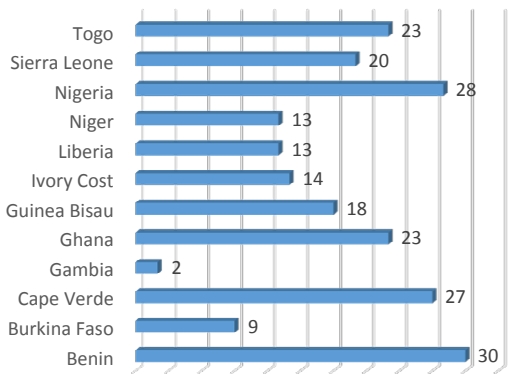

Figure 2: Scores of member states in this study.

\section{General Information on Structure}

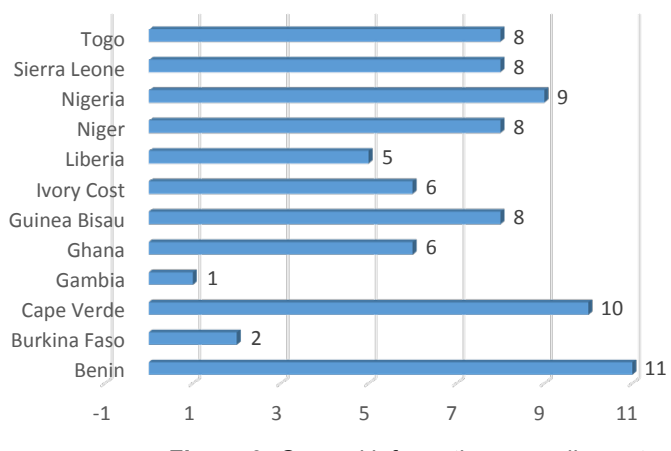

Figure 3: General information on parliament. access the parliament and a guided tour, a functional organizational chart, composition of the parliament (unicameral or bicameral), pictures and diagrams of the chamber(s), news and press releases, description of official functions and contact information for each body and a location map of the parliament, possibly using google map. Seven out of the twelve parliaments previewed implemented over $50 \%$ of the features under this vital category, however such score is poor considering that the general information of a parliament is the first interface for public understanding of how their legislature work.

\section{Electoral systems and parties}

Under this category, information about electoral systems and procedures, political parties involved, party affiliations and constituencies in a nation, results of the last elections, followed by some analysis based on gender, age, etc., and the performance of each party are required. All the assessed parliaments scored none or less than 1 out of $6(16.7 \%)$ features under this category. According to the IPU guidelines, explanation of the electoral system helps site visitors to know the procedures of election upon which legislators got into the parliament. Even the parliamentary websites of countries like Nigeria and Burkina Faso that had elections in 2015 with dramatic results, could not dedicate a page on the analysis of their general elections and a link to their electoral commissions, the existence of which many site visitors from outside may not know.

\section{Legislative process and documents}

Under this category four features are considered: Summary explanation of legislative process, Legislative agendas, a database of legislative documents, and the status of bills and bill tracking.

The most sought after information by citizens from parliamentary websites are the laws they are making. Several of the ECOWAS member's parliaments have posted scanty number of laws, except Nigerian Parliament that have a fairly adequate amount of current bills and laws passed into acts. From the perspective of inquiries, bills need to be searchable, downloadable and their status verifiable from a parliamentary website. Close to $98 \%$ of countries assessed could not give the status of current bills or their track (Table 2).

\section{Presiding officers of the parliament}

Only two member countries are bi-cameral, Nigeria and Liberia, but in both countries, the Senate President is the number 3 person in the hierarchy of power in the two respective countries. The rest of the surveyed countries have presidents of the parliaments around whom the management of the parliament and political structure revolve. Six features are scored under this category, they are: Bio data of presiding officers, Presiding Officers Public Agendas, Social Media Widgets, Important Speeches, List of Past Presiding Officers, Comments and Questions for Presiding Officers (Figure 4).

Up to 7 countries scored less than $50 \%$ of the requirements under this category, leaving only Togo, Benin and Sierra Leone who scored $50 \%$ and above. The central problem has to do with opening windows for contact between the public and presiding officers of the parliament

\begin{tabular}{|l|c|c|}
\hline Features & Yes & No \\
\hline Summary Explanation of Legislative Process & $8(66.67 \%)$ & $4(33.33 \%)$ \\
\hline A Database of Legislative Documents & $7(58.33 \%)$ & $5(41.67 \%)$ \\
\hline Legislative Agendas & $3(25 \%)$ & $9(75 \%)$ \\
\hline Status of Bills and Bill Tracking & $1(8.33 \%)$ & $11(97.67 \%)$ \\
\hline
\end{tabular}

Table 2: Legislative process and documents. 


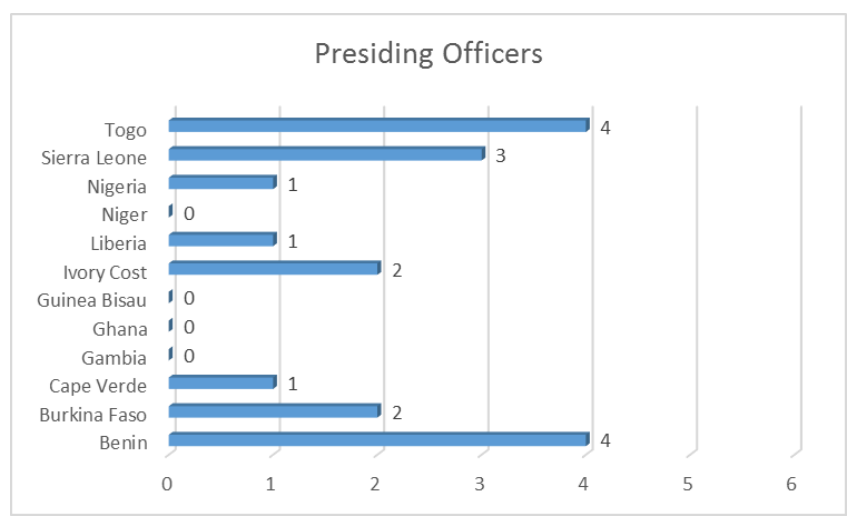

Figure 4: Scores on presiding officers' information.

through the social media widget and a contact and feedback page that ensures presiding officers address questions from the public or comment on issues that may require clarifications to the public. Only one parliament each indicate active Social Media Widget $(8.33 \%)$ and a window for comments and questions (8.33\%) for presiding officers. This evident reticence by legislators is noted by Pellizo [5] who attributes it to either ignorance in the use of the internet or deliberate uncommunicativeness by legislators who he observes hardly use their official webmail boxes. Although studies show the low-quality of on-line deliberations, a structured format that can resemble formal public hearings can be adopted by African parliaments. Opening windows for structured inputs e.g. e-petition, e-view, etc. can force on-line participants to conform to certain expectations of intellectual inputs and thereby broaden public deliberation on issues rather than restricting it to the dwellers of the parliament city.

\section{Parliamentary bodies}

This refers to non-plenary parastatals of the parliament that are established specifically to support parliament. Such bodies could be institutes like the Institute for Legislative Studies of Nigeria or bodies like Population and Development of Cape Verde. The category scored websites on Non Parliamentary Bodies and their links, a short description of the bodies, contact information on the bodies and the composition of the bodies. It is difficult to ascertain from the websites if other parliaments apart from Nigeria and Cape Verde have parastatals. In both Cape Verde and Nigeria, the links to the parastatals are not preceded by explanatory details of the bodies (Figure 5).

\section{Publications}

Parliamentary publications are very important, not only for the citizens but for the legislators themselves, their staff, students and various researchers. Before the advent of websites, parliamentary publications were given on request but today, online, the latest copies of debates and laws are made available on websites. Under this category, the guidelines recommend the websites to provide a list of available publications and documents, information on how to obtain the publications, downloadable publications and the resources in the library and archives and how to access them. However as can be glean from Table 3 over $80 \%$ of websites assessed scored very low on information on publications and the accessibility of library and archival resources. Lack of skilled personnel and ICT resources could appear to be delaying the building of accessible repositories of parliamentary laws and publications in the ECOWAS websites [10].

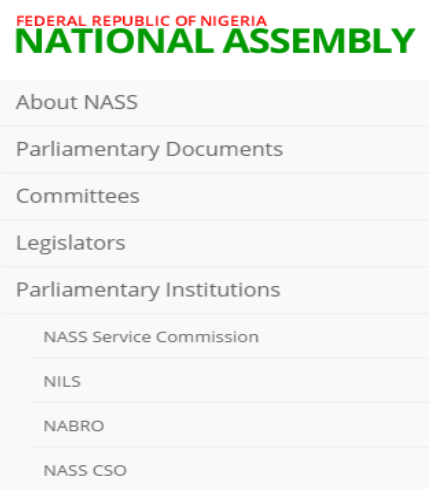

Figure 5: The menu showing parliamentary bodies of Nigerian parliament.

\begin{tabular}{|l|c|c|}
\hline Features & Yes & No \\
\hline List of Parliamentary Publications and Documents & $6(50 \%)$ & $6(50 \%)$ \\
\hline Information on how to Obtain Publications & $1(8.33 \%)$ & $11(91.67 \%)$ \\
\hline Downloadable Publications & $4(33.33 \%)$ & $8(66.67 \%)$ \\
\hline Are Library and Archives Accessible & $2(16.67 \%)$ & $10(83.33 \%)$ \\
\hline
\end{tabular}

Table 3: Parliamentary publications.

\begin{tabular}{|l|c|c|}
\hline Features & Yes & No \\
\hline Historical Audio Video on Parliament & $3(25 \%)$ & $9(75 \%)$ \\
\hline Educational Audio Video on Parliament & $1(8.33 \%)$ & $11(91.67 \%)$ \\
\hline Webcast of Plenary Sessions & $2(16.67 \%)$ & $10(83.33 \%)$ \\
\hline Webcast of Hearings and Committee Sittings & $1(8.33 \%)$ & $11(91.67 \%)$ \\
\hline \multicolumn{2}{|c|}{ Table 4: Multimedia in ECOWAS parliaments. }
\end{tabular}

\section{Electronic media}

Under the above category, the [11] guidelines focus on webcasting or live streaming of parliamentary activities and the capacity to archive recorded activities for on-demand viewing. The following features are assessed: Historical audio video on the parliament commemorating momentous occasions, Educational audio video that can, in a multimedia form, explain process of legislature for the youth, Webcasting or streaming of plenary sessions in addition to traditional TV or radio broadcast of the parliament, Webcasting or streaming of important public hearings and committee sittings (Table 4).

Guinea Bissau parliament scored $100 \%$ under this category, followed by Nigeria $50 \%$ and Ghana. The remaining nine parliaments have no multi-media resources on their websites. Webcasting is essentially broadcasting on World Wide Web, promising better scope of coverage than terrestrial or satellite broadcasting. With a reduced coast in setup and receiving technology, it promises both on-demand and live streaming of events, making it a cost-effective technology for African parliaments to adopt. However the challenges of bandwidth, appropriate receivers (computers and handsets), and ICT literacy across African communities makes it still an elitist narrow-casting medium that is the privilege of the few [12].

\section{External links}

According to IPU [13] "Internet users should be able to find their way easily from a national parliament's Web site to those of political parties and government institutions, other countries' parliaments, inter-parliamentary structures, and so on. The actual number and scope of links may vary greatly depending on the degree of presence of 
Citation: Hamajoda A (2016) Informing and Interacting with Citizens: A Strategic Communication Review of the Websites of the ECOWAS Parliaments J Mass Communicat Journalism 6: 295. doi:10.4172/2165-7912.1000295

State institutions of a given country on the Internet and the ability of the site's Webmaster to keep all links up to date".

Five countries Niger, Liberia, Gambia, Cape Verde and Burkina Faso have not implemented the category at all (Figure 6), which features link to Federal Parastatals and Ministries, States and Provincial Websites, International Regional and Sub-regional Organizations, National Website, National Political Parties, and relevant NGOs and Civil societies. This category is very crucial considering the need for parliamentary websites to be one-stop points for political information on their respective countries. Even from the ECOWAS objectives point of view, member states websites need to provide prefaced links to the ECOWAS Commission \& central parliament website, and links to other member states websites.

\section{Feedback and other interactivity tools}

This is the most important category in view of the new objectives of ECOWAS and the future of political communication in Africa. Unfortunately it is also the least developed after External Links category among websites. The rudimentary features of Feedback Form Direct to Webmaster, Electronic Mail, Opinion Polls, Social Media Forums and Mailing List are used to assess the websites. Kindra [3] show how Africa represents the lowest penetration of internet by region although internet users' increase of recent has surpassed that of the Middle East and Oceania. With the hope for increased internet and mobile cellular phones and tablets, the landscape of political communication may change in the ECOWAS sub region. The parliaments have already scored well in social media forums, with many legislators using Facebook and twitter widgets, however greater openings for deliberations and interaction with the citizens is required, considering that only one parliament is polling on issues (Table 5) and $98 \%$ of the parliaments presiding officers offer no window for interaction or inquiries from citizens.

\section{Conclusions}

Although, the usage of the internet is still restricted to the

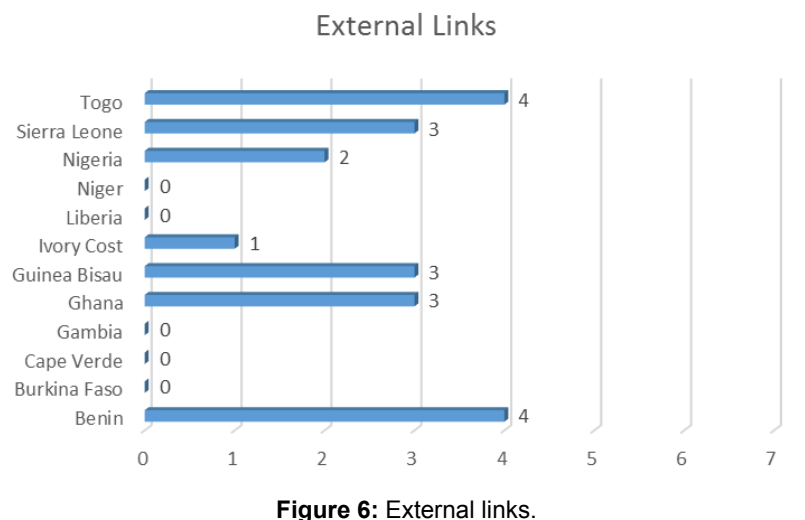

Figure 6: External links.

\begin{tabular}{|l|c|c|}
\hline Features & Yes & No \\
\hline Feedback Form Direct to Webmaster & $7(58.33 \%)$ & $5(41.67 \%)$ \\
\hline Electronic Mail & $5(41.67 \%)$ & $7(58.33 \%)$ \\
\hline Opinion Polls & $1(8.33 \%)$ & $11(91.67 \%)$ \\
\hline Social Media Forums & $4(33.33 \%)$ & $8(66.67 \%)$ \\
\hline Mailing Lists & $1(8.33 \%)$ & $11(91.67 \%)$ \\
\hline
\end{tabular}

Table 5: Feedback and interactivity tools. privileged few in Africa, strengthening the internet interactive and communication tools will in no small measure broaden and improve political communication and policy deliberation between citizens and the legislators. Two of the four components of ECOWAS new communication strategy [2] are stated as 'population participation in action and their feed-back' and 'conscious awareness activities and mobilization of the West African Citizens'. The interactive and twoway communication tools deployable on websites can greatly enhance the above communication objectives of ECOWAS. It is expected that as citizens are politically sensitize, they will increasingly demand to know about the stance of legislators on certain issues and will want some forms of responses and acknowledgements. It is apparent from the analysis, that going forward in their current website enhancements that member states try to improve the following features: first, the websites as much as possible, need to provide one-stop avenues for political information on a country. Visitors should be able to find out about latest election results in a digest form, party systems, current national budgets and their performances, various National institutions and parastatals, relevant internal and external organizations that are related to democratic development, prefaced link to ECOWAS Commission website with introductory information on the commission and its targets, link to other ECOWAS members' websites, etc. Second, websites need to open windows of interactive communication with citizens using various input forms, polling widgets, blogs, online forums, mobile alerts and services, e-petitions, and various other methods as they emerge including initiating dialogues on key ECOWAS targets and challenges in addition to national issues. The Declaration of Parliamentary Openness [7], has specified legislative information as belonging to the public and has therefore called on parliaments to engage their citizens in a transparent and accessible ways [14].

\section{References}

1. ECOWAS (2014) ECOWAS Vision 2020: Towards a Democratic and Prosperous Community.

2. Sanankoua AK (2011) The Ecowas New Communication Policy: Four Mains Channels for Proximity Information to Populations.

3. Kindra G, Stapenhurst F (2010) Empowering Parliaments with Strategic Communications, World Bank Institute 1-44.

4. Coleman S (2004) Connecting Parliament to the Public via the Internet: Two Case Studies of Online Consultations. Information, Communication and Society 7: 1-17.

5. Pelizzo R, Kindra G, Stapenhurst F (2013) ICT and the transformation of political communication. International Journal of Advances in Management Science 2: 32-42.

6. Oni SA, Charles O, Aderonke DM (2015) Electronic Enabled CitizensParliament Interaction: Imperative for Democratic Governance in African States. Proceedings of the European Conference on e-government, Nigeria.

7. World e-Parliament (2012) The Declaration on Parliamentary Openness Opening Parlaiment.Org.

8. Opening Parliament.org (2012) Declaration on parliamentary openness.

9. Brassard D (2006) 'How can Information Technology Transform The way Parliament Works' Library of Parliament, Canadian Parliament.

10. Global Centre for ICT in Parliament (2010) World e-Parliament Report 2010 IPU, Geneva.

11. IPU (Inter-Parliamentary Union) (2009) Guidelines for Parliamentary, Geneva.

12. Global Centre for ICT in Parliament (2012) World e-Parliament Report 2012 IPU, Geneva.

13. Dahlgren $P$ (2005) The Internet, Public Spheres, and Political Communication Dispersion and Deliberation. Political Communication 22: 147-162.

14. Tsaliki L (2002) Online Forums and the Enlargement of the Public Sphere Research from a European project. The Public 9: 95-112. 